\title{
CROSS-BORDER COOPERATION IN SLOVAK-CZECH BORDER REGION UNDER EU PROGRAMMES
}

\author{
Eva Rajčáková ${ }^{1}$, Angelika Švecová $^{2}$
}

Received 19 December 2012; Accepted 16 May 2013

\begin{abstract}
Cross-border cooperation is one of the development opportunities of border regions. Cross-border cooperation (CBC) along the Slovakia-Czech border is specific. It is due to several factors like common history under one state formation, historical ties and similarity of language and culture. Cooperation was realised also in the past. CBC got new forms and intensity after the peaceful dissolution of Czechoslovakia in two independent states - Czech Republic and Slovak Republic and the possibility to draw support from EU instruments for cross-border cooperation in the pre-accession (after 2003) and the programming periods 2004-2006 and 2007-2013. The aim of this contribution is to highlight the implementation status and opportunities of Operational Programme Cross-Border Cooperation Slovak Republic - Czech Republic 2007-2013 (OP CBC SK-CZ 2007-2013) and at a lower administrative level to evaluate the potential of local governments of the Trenčín Self-Governing Region (TSR) and three border self-governing regions (Trnava, Trenčín, Žilina) for involvement in cross-border cooperation. In the current programming period of 20072013, cross-border cooperation is implemented also in the Slovakia-Czech border region under the OP CBC SK-CZ 2007-2013. Research pointed to a lower intensity of drawing funds on OP CBC SK-CZ 2007-2013. The main reasons are the lack of experience of local governments with grant applications, project implementation and difficult project administration. The problem is also long term of verification of the financial costs of the project activities what gets municipalities into trouble with co-financing of projects. It caused that municipalities have low interest to apply for new projects.
\end{abstract}

Key words: Cross-border cooperation, Slovak Republic, Czech Republic, Operational programme CBC

Abstrakt: Jednou z možností rozvoja cezhraničných regiónov je cezhraničná spolupráca. Cezhraničná spolupráca pozdĺž slovensko-českej hranice je $v$ dôsledku viacerých skutočností (spoločná minulost' v rámci jedného štátneho útvaru, historické väzby, podobnost' jazyka a kultúry) špecifická. Spolupráca sa realizovala aj v minulosti,

\footnotetext{
${ }^{1}$ Doc. RNDr. Eva Rajčáková, CSc., Department of Regional Geography, Protection and Planning of the Landscape, Faculty of Sciences, Komenský University, Mlynská dolina B1, 84215 Bratislava 4, Slovakia; e-mail: rajcakova@fns.uniba.sk

2 RNDr. Angelika Švecová, Ph.D., Department of Regional Geography, Protection and Planning of the Landscape, Faculty of Sciences, Komenský University, Mlynská dolina B1, 84215 Bratislava 4, Slovakia; e-mail: asvecova@fns.uniba.sk
} 
avšak nové formy a intenzitu nadobudla po rozdelení a vyhlásení samostatnosti Českej a Slovenskej republiky a v súvislosti s možnost'ou čerpat' podporu z nástrojov EÚ na cezhraničnú spoluprácu $v$ rámci predvstupového (po roku 2003) a programových období 2004-2006 a 2007-2013. V súčasnosti sa cezhraničná spolupráca v slovensko-českom cezhraničnom regióne realizuje v súlade s Operačným programom Cezhraničná spolupráca SR-ČR 2007-2013 (OP CBC SK-CZ 2007-2013). Ciel'om príspevku je poukázat' na možnosti a stav implementácie OP CBC SK-CZ 2007-2013 a na nižšej hierarchickej úrovni vyhodnotit' predpoklady samospráv obcí TSK a prihraničných samosprávnych krajov (Trnavský, Trenčiansky, Žilinský) na cezhraničnú spoluprácu. Výsledky výskum poukázali na nižšiu intenzitu čerpania finančných prostriedkov z OP CBC SK-CZ 2007-2013. Príčinami sú najmä nedostatok skúseností samospráv so žiadost'ou o dotáciu a implementáciou cezhraničných projektov a náročná administrácia projektov. Nezanedbatel'né je dlhé obdobie potrebné na overenie finančných nákladov projektových aktivít, čo dostáva obce do problémov so spolufinancovaním projektov a prejavuje sa aj nízkym záujmom obcí uchádzat' sa o nové projekty.

Klúčové slová: Cezhraničná spolupráca, Slovenská republika, Česká republika

\section{Introduction}

Cross-border cooperation is one of the forms of the border regions development. Cross-border cooperation along the Slovakia-Czech border has a long tradition.

Czech-Slovak border cooperation is quite specific due to common history, historical ties, mutual proximity, similarity of language and culture of the Czech Republic and Slovak Republic. Mutual cooperation has already taken place under the Czech and Slovak Socialist Republic and Czecho-Slovak Federal Republic. In view of common state, the real state border has never been there and the cooperation of municipalities from both sides of the border had not the nature of cross-border cooperation as it is conceived in present. Mutual cooperation was carried out mainly between municipalities, which lie directly, or at a short distance from the imaginary boundaries. Cooperation had socio-cultural character and it was used to fixing family and neighborly relations.

\section{Brief survey of the development of CBC in Slovakia}

After 1989, both countries have gone through a process of transformation, which is also reflected in bilateral and cross-border cooperation. It was mainly the activities of local and regional initiatives, especially at the local governmental level (activities of the type "bottom-up"). Legislative conditions (Act No. 369/1990) provided competences to local self-governments for building relations in the frame of international cooperation. In practice there was prevailing distrust of such agreements.

The new period of CBC started after the Law of the Territorial-administrative Division (in 1996) was adopted. In accordance with this law municipalities were given extended competences and the opportunity to enter international cooperation and become members of international regional associations or authorities. After 2001 there was even higher support for municipalities, actors and partners in CBC. Legislative, programmed and financial support was realized in programmes of pre-accession assistance (Phare CBC, INTERREG) and next in the programming period 2004-2006. During this period most of Euro-regions have been established (13), and Euro-regional and cross-border cooperation have been also developed. In programming period 2007-2013 the CBC was supported from the third target of European Cohesion policy - European territorial cooperation (Table 1). All territorial units NUTS 3 were eligible - that is, all regions of Slovakia.

After the peaceful dissolution of Czechoslovakia into two independent states - Slovak Republic and Czech Republic and the accession of the Czech Republic and the Slovak Republic to the EU, cross-border cooperation is developed under the EU programmes. Cross-border cooperation has different forms and its intensity is affected by a large number of factors. 
At present, Slovak and Czech cross border cooperation is realized under the Operational Programme CBC SK-CZ 2007-2013. The overall objective of the OP CBC SK-CZ 2007-2013 is "growth of cohesion and convergence of the border region", which includes the creation of functional networks of cooperating bodies in an effort to promote the sustainable integrated economic, social, environmental and cultural development of the region by improving the availability, development of informatization, tourism, and the preservation and development of cultural traditions (OP CBC SK-CZ 2007-2013, p. 37).

The Operational Programme CBC SK-CZ 207-2013 is intended for the Czech regions of South Moravia, Moravia-Silesia and Zlín, and the regions of Trenčín, Trnava and Žilina on the Slovak side.

\begin{tabular}{|c|c|}
\hline Priority axis & Measures \\
\hline \multirow{6}{*}{$\begin{array}{l}\text { 1.Support of Social-Cultural and } \\
\text { Economic Development of Cross- } \\
\text { Border Region and Cooperation }\end{array}$} & 1.1 Cultural development and preservation of traditions \\
\hline & 1.2 Cooperation and networking \\
\hline & 1.3 Education, labour market and employment \\
\hline & $\begin{array}{l}\text { 1.4 Development of entrepreneurial and innovation } \\
\text { environments }\end{array}$ \\
\hline & 1.5 Development of cross-border tourism \\
\hline & 1.6 Fund of micro-projects \\
\hline \multirow{3}{*}{$\begin{array}{l}\text { 2.Development of Accessibility of the } \\
\text { Cross-Border Territory and } \\
\text { Environment }\end{array}$} & $\begin{array}{l}\text { 2.1 Development of transport infrastructure and accessibility of } \\
\text { border regions }\end{array}$ \\
\hline & 2.2 Environmental conservation and development of the country \\
\hline & $\begin{array}{l}2.3 \text { Improving information and communication accessibility of } \\
\text { border regions }\end{array}$ \\
\hline 3.Technical assistance & Management and implementation of the programme \\
\hline
\end{tabular}

Tab 1. Priority axis and measures of the Operational Programme CBC SK-CZ 2007-2013.

Source: http://eurofondy.webnode.sk/slovenska-republika-ceska-republika/, [20.9.2012].

A total of EUR 92.74 million was allocated for this Programme. Of this, EUR 50.1 million $(54.8 \%)$ has been allocated for the $1^{\text {st }}$ priority axis Support of Social-Cultural and Economic Development of Cross-Border Region and Cooperation. EUR 37.1 million (40\%) are intended for the $2^{\text {nd }}$ priority axis Development of Accessibility of the Cross-Border Territory and Environment. EUR 5.6 million $(5.2 \%)$ are for $3^{\text {rd }}$ priority axis Technical Assistance.

In the Priority Axis 1, the largest amount of funding has been allocated to Measure 1.5 Development of Cross-border Tourism (EUR 10.39 millions), Measure 1.6 Micro-projects fund (EUR 9.27 mil.) and Measure 1.2 Cooperation and Networking (EUR 9.13 mil.). In Priority Axis 2 the largest volume of funds is allocated to Measure 2.1. Development of Transport Infrastructure and Accessibility (EUR 16.69 millions) and Measure 2.2 Sustainable Environment and Development of the Country (EUR 11.13 million).

Municipalities, public administration, self governing regions, non-profitable organizations, economic and agricultural chambers, and schools can ask for this support.

\section{Theoretical background}

In the literature (Anderson et al 2003, Falt’an 2005, Halás 2005, Halás, Slavík 2001, Scherer et al 1995, Ricq 2006) we can meet with several definitions for a border (frontier) region and crossborder cooperation. Generally, a border region can be considered the territory contiguous to the frontier, respectively to the territorial unit that shares a common border with one or more territorial units of the same type located in a neighbouring country (European Council 1998, In Rajčáková, 2009, p. 63).

A trans-frontier region is a potential region, inherent in geography, history and ecology, ethnic groups, economic opportunities and so on, but disrupted by the sovereignty of the governments ruling on each side of the frontier (Rougemont 1978, In Rajčáková, 2009, p. 63).

The term trans-frontier cooperation means any concerted action designed to reinforce neighbourly relations between territorial communities or authorities within the jurisdiction of two or more contracting parties, and the conclusion of any agreement and arrangement necessary 
for this purpose. (European Outline Convention on Trans-frontier Co-operation between Territorial Communities or Authorities, 1980)

Cross-border cooperation is regional and local cooperation among bodies lower than governmental level on both sides of the state border, which helps to promote peace, freedom, the security and safeguarding of human rights, encourages the protection of ethnic and national minorities, and leads to the development of cross-border regions (European Charter of Border and Crossborder Regions, 1995).

Cross-border relations represent a complex of all processes that are a result of the dependence of a territory from one side of the state border on the potential of a territory from the other border side (Halás, 2005, p. 12).

In the broad European context, CBC creates a contiguous system of cross-border structures along the common border, which are involved in integration processes in Europe (Dočkal, 2005, p. 14).

According to the Council of Europe, all activities aimed at strengthening and promoting neighbourly relations between inhabitants of borderlands on both sides of the common State border are considered to be cross-border cooperation. The given activities make a basis for meeting its main objective - unification to the greatest degree possible of European countries and their populations (Marhulíková, 2005, In: Halás, 2007, p. 24).

Cross-border cooperation is the most effective instrument to gradually reduce the effect of the border, a precondition for the establishment of integration processes at the regional (local) level, and forming regions exceeding national border - cross-border regions (Halás, Slavík, 2001, p. 171).

Cross-border cooperation can be implemented at different levels, has different intensity and is influenced by many factors (historical development, language barriers, the nature of economic structures, conditions created by government (Hermanová, 2005, p. 7).

The result of $\mathrm{CBC}$ is dependent on subsidiary, the level of partnership, common development strategies and structures at the regional (local) level, and sources of funding (Gabbe, 2004, In Falt'an, 2005, p. 9).

\section{Methodological approach}

The overall objective of the study is to evaluate the efficiency of the implementation of the Operational Programme CBC SK-CZ in the period 2007-2013. The specific objectives are:

- evaluation of municipalities assumption for CBC,

- evaluation of the potential and assumptions for increased intensity for CBC of municipalities in TSR according to selected factors,

- evaluation of the spatial differentiation of villages in the Slovak part of the border region by the number of partner projects implemented under the OP CBC SK-CZ 2007-2013.

In this paper we set the following hypotheses:

- Municipalities located at the state border are increasingly involved in cross-border cooperation,

- Municipalities with agreement for partnership cooperation can get easier a partner for the CBS project,

- Municipalities with experience in applying for the grant in programming period 20042006 are also active in the 2007-2013 period,

- Municipalities with existing development programming documents (Programme of economic and social development, Land use plan, Programme of tourism development, Programme of housing development) are active in projects of CBC.

In the study, official data were used about the proposals and finance spending of the CBC OP SK-CZ 2007-2013 from the governing body - the Ministry of Agriculture and Rural Development 
of the Slovak Republic. The results of the questionnaire survey were the input data for the evaluation of assumptions of municipalities in TSR for CBC. The survey ran from 09/2011 to 03/2012.

In the research we assumed that the local governments of TSR municipalities have different attitudes and experiences with applying for support from EU funds and the implementation of cross-border projects. The research was aimed at obtaining information on the state (value) of selected factors that the authors considered significant in terms of their impact on the intensity of cross-border cooperation in the region. These factors influenced the efficiency of CBC in different intensity.

The factors which influenced the efficiency of cross-border cooperation:

-Accessibility of the nearest border point (factor 1) - accessibility (distance) of the village to the nearest border crossing on a road of $1^{\text {st }}$ to $3^{\text {rd }}$ class (indicator: $\mathrm{km}$ )

-Partner municipalities (factor 2) - municipalities of Czech part of cross-border region which have signed a partnership agreement on CBC with municipalities of TSR (indicator: number of municipalities)

- Experience with the application for grants in Programmes CBC 2004-2006 (factor 3) the precondition for further development of the project cooperation is that municipalities that have experience in preparing project applications are also actively involved in the current programming period (indicator: number of prepared and submitted grant applications in INTERREG IIIA SK-CZ)

-Implementation of projects under the CS 2004-2006 (factor 4) - it is assumed that municipalities with experience of the implementation of cross-border projects are active in the current programming period (indicator: the number of projects implemented under INTERREG IIIA SK-CZ)

-Programme Documents of municipalities (factor 5) - the number of programme documents (Programme of economic and social development, Land use plan, Programme of tourism development, Programme of housing development), which declared development objectives that can be potentially realized under OP CBC SK-CZ 2007-2013 (F5) (indicator: the number of programme documents)

In the framework of this research, several methods and working procedures were used. The questionnaire survey was focused on finding values for factors 1 to $5.167(60.5 \%)$ of 276 municipalities of TSR participated in the questionnaire survey, We used Method of expert evaluation: The factors 1 to 5 signed different value for CBC efficiency. 15 independent experts (government workers, experts with experience in cross-border cooperation, academics) and students of regional geography at Faculty of Natural Sciences in Bratislava have determined the order of importance for factors 1 to 5 .

The next step was the allocation of the weights (importance) for factors 1 to 5 according to expert evaluation, and to elaborate a scoring system for the empirical data of factors 1 to 5 obtained by the questionnaire survey (Table 2).

It was used to express the partial and total potential of municipalities in TSR for CBC. Partial potential of villages for $\mathrm{CBC}$ is determined by multiplying the value of indicators (empirical data obtained by questionnaire survey) and the factor of importance (weight). The total potential of municipalities in TSR for CBC is the sum of the partial potentials and the basis for typology of TSR villages by the potential for CBC (municipalities with low, moderately high and high potential). For the presentation of spatial differentiation of assumptions for the development of CBC and implemented projects for CBC in municipalities of TSR in OP CBC SK-CZ 2007-2013, ArcGIS was used. 


\begin{tabular}{|c|c|c|c|c|c|c|c|c|c|}
\hline \multicolumn{2}{|c|}{$\begin{array}{l}\text { Accessibility of } \\
\text { the nearest } \\
\text { cross border } \\
\text { point } \\
\text { (factor } 1 \text { ) }\end{array}$} & \multicolumn{2}{|c|}{$\begin{array}{c}\text { Partner } \\
\text { municipalities } \\
\text { (factor 2) }\end{array}$} & \multicolumn{2}{|c|}{$\begin{array}{l}\text { Experience with } \\
\text { the application for } \\
\text { grants in } \\
\text { Programmes CBC } \\
2004-2006 \\
\text { (factor 3) }\end{array}$} & \multicolumn{2}{|c|}{$\begin{array}{c}\text { Implementation } \\
\text { of projects under } \\
\text { the CBC 2004-2006 } \\
\text { (factor 4) }\end{array}$} & \multicolumn{2}{|c|}{$\begin{array}{c}\text { Programme } \\
\text { Documents of } \\
\text { municipalities } \\
\text { (factor 5) }\end{array}$} \\
\hline $\mathrm{Km}$ & $\begin{array}{c}\text { Point } \\
s\end{array}$ & $\begin{array}{c}\text { Number } \\
\text { of } \\
\text { Municipalities }\end{array}$ & Points & $\begin{array}{l}\text { Number of } \\
\text { Application } \\
\text { for Grants }\end{array}$ & Points & $\begin{array}{c}\text { Number of } \\
\text { Implemented } \\
\text { Projects }\end{array}$ & Points & $\begin{array}{l}\text { Number of } \\
\text { Programme } \\
\text { Documents }\end{array}$ & Points \\
\hline $0-25$ & 4 & more than 4 & 4 & $\begin{array}{c}\text { more than } \\
4\end{array}$ & 4 & more than 4 & 4 & $\begin{array}{c}\text { more than } \\
4\end{array}$ & 4 \\
\hline $26-50$ & 3 & 3 & 3 & 3 & 3 & 3 & 3 & 3 & 3 \\
\hline $51-75$ & 2 & 2 & 2 & 2 & 2 & 2 & 2 & 2 & 2 \\
\hline $76-100$ & 1 & 1 & 1 & 1 & 1 & 1 & 1 & 1 & 1 \\
\hline $\begin{array}{l}\text { more } \\
\text { than } 101\end{array}$ & 0 & 0 & 0 & 0 & 0 & 0 & 0 & 0 & 0 \\
\hline
\end{tabular}

Tab 2. Scoring system for factors 1 to 5. Source: Questionnaire survey, 09/2011-03/2012.

\section{Results and discussion}

At present Slovak and Czech republics are in an advanced stage of implementation of the OP CBC SK-CZ 2007-2013, which allows to express some opinions on the partial results and success of its implementation. Until now there were 3 calls, with 537 applications (of which there were 260 (48\%) with leading partners on the Slovak side) under OP CBC SK-CZ 20072013. The greatest interest of applicants was in the first call (249,46\% of all applications) however, only $1 / 3$ of leading partners came from the Slovak Republic. The number of applications of the second (137) and the third call (151) was very similar, but there was much greater interest from Slovak leading partners (the second call-81/59.1\%, the third call $96 / 63.6 \%)$.

\begin{tabular}{|l|c|c|c|c|}
\hline Address of lead partner & I. Call & II. Call & III. Call & Total \\
\hline Czech Republic & 166 & 56 & 55 & 277 \\
\hline Slovak Republic & 83 & 81 & 96 & 260 \\
\hline Total & $\mathbf{2 4 9}$ & $\mathbf{1 3 7}$ & $\mathbf{1 5 1}$ & $\mathbf{5 3 7}$ \\
\hline
\end{tabular}

Tab 3. Project applications according to address of lead partner (OP CBC SK-CZ 2007-2013). Source: Ministry of Agriculture and Rural Development of the Slovak Republic, 2012.

Of the total number of grant applications (537), 175 were approved and 171 projects were contracted and they are currently in process of implementation. Only one third (59) of supported projects have been already successfully finished.

\begin{tabular}{|c|r|r|r|r|}
\hline \multicolumn{1}{|c|}{ Priority axis } & \multicolumn{1}{c|}{$\begin{array}{c}\text { Submitted } \\
\text { projects } \\
\text { (number) }\end{array}$} & $\begin{array}{c}\text { Rejected } \\
\text { projects } \\
\text { (number) }\end{array}$ & $\begin{array}{c}\text { Approved } \\
\text { projects } \\
\text { (number) }\end{array}$ & $\begin{array}{c}\text { Certified } \\
\text { projects } \\
\text { (number) }\end{array}$ \\
\hline $\begin{array}{c}\text { 1.Support of Social-Cultural and } \\
\text { Economic Development of } \\
\text { Cross-Border Region and } \\
\text { Cooperation }\end{array}$ & 347 & 222 & 125 & 50 \\
\hline $\begin{array}{c}\text { 2.Development of Accessibility of } \\
\text { the Cross-Border Territory } \\
\text { and Environment }\end{array}$ & 183 & 140 & 43 & 9 \\
\hline 3.Technical Assistance & 7 & 0 & 7 & 0 \\
\hline OP CBC SK-CZ 2007-2013 & $\mathbf{5 3 7}$ & $\mathbf{3 6 2}$ & $\mathbf{1 7 5}$ & $\mathbf{5 9}$ \\
\hline
\end{tabular}

Tab 4. Implementation of the OP CBC SK-CZ 2007-2013 (Number of projects). Source: Ministry of Agriculture and Rural Development of the Slovak Republic, 2012.

According to the received applications, there was most interest for projects within the $1^{\text {st }}$ Priority axis (347 projects, $64 \%$ of applications). 125 (36\%) were also approved and 123 projects were contracted. 50 projects were also successfully completed (Table 4). 
The total amount of approved budgets under the OP CBC SK-CZ 2007-2013 is EUR 77.57 million, but so far only EUR 32.44 million (35\%) were actually spent. The amount of financial drawing is different according to priorities and measures. The highest is in Measures $1.1(96 \%), 1.5(74 \%), 1.2$ and 2.2 (both around 32\%).

There is a significant difference between the amount of financial drawing and the amount of financially closed projects (EUR 14.61 millions, 20.31\%). Many projects one year before the end of the Programming Period 2007-2013 are in the position of implementation or after the implementation of activities. At present, the verifying of the correctness of their financing is in progress, but it usually takes too long and negatively affects the amount of spending of successfully completed projects, which is currently quite low.

\begin{tabular}{|c|c|c|c|c|c|}
\hline \multirow{2}{*}{ Priority axis } & \multirow{2}{*}{$\begin{array}{c}\text { EU } \\
\text { Contribution } \\
\text { 2007-2013 } \\
\text { (mil. EUR) }\end{array}$} & \multirow{2}{*}{$\begin{array}{l}\text { Approved } \\
\text { operations } \\
\text { budget } \\
\text { (mil.EUR) } \\
\end{array}$} & \multicolumn{2}{|c|}{$\begin{array}{c}\text { Realised / declared } \\
\text { expenditure }\end{array}$} & \multirow{2}{*}{$\begin{array}{l}\text { Certified } \\
\text { budget } \\
(\%)\end{array}$} \\
\hline & & & (mil. EUR) & $\%$ & \\
\hline $\begin{array}{l}\text { 1.Support of Social-Cultural } \\
\text { and Economic } \\
\text { Development of Cross- } \\
\text { Border Region and } \\
\text { Cooperation }\end{array}$ & 50.08 & 44.49 & 22.16 & 44.25 & 23.02 \\
\hline $\begin{array}{l}\text { 2.Development of Accessibility } \\
\text { of the Cross-Border } \\
\text { Territory and Environment }\end{array}$ & 37.10 & 27.61 & 8.90 & 23.99 & 8.30 \\
\hline 3.Technical Assistance & 5.56 & 5.56 & 1.37 & 24.64 & 0 \\
\hline OP CBC SK-CZ 2007-2013 & 92.74 & 77.57 & 32.44 & 34.98 & 15.75 \\
\hline
\end{tabular}

Tab 5. Implementation of the OP CBC SK-CZ 2007-2013. Source: Ministry of Agriculture and Rural Development of the Slovak Republic, 2012.

The current state has several reasons. The first calls for the applications were actually announced to a year after the beginning of the programming period. Administrative problems are reflected in the slowdown in the process of implementation of OP CBC SK-CZ 2007-2013 compared to the expected timetable. There we can follow the partial lack of interest of authorized subjects in submission of applications for projects. Global reason is the economic crisis, which negatively affects possibility of potential beneficiaries for co-financing projects.

The next part of the study was aimed at evaluation of the potential of municipalities in TSR for $\mathrm{CBC}$. Using the methods outlined in the previous section, we came to a series of interesting findings.

$167(60.5 \%)$ municipalities participated in the questionnaire survey. There were 13 towns and 154 rural settlements. Participation of municipalities was differentiated by districts (max. Prievidza 33/63.5\%; Bánovce Bebravou 30/69.8\%; min. Ilava 9/42.9\%; Myjava 9/52.9\%). Based on historical experience and character of cooperation, which for a long time have had a sociocultural nature and contribute to the development of family ties we assumed that the municipalities located immediately near the border or a short distance from were more likely to actively participate in the questionnaire survey due to their experience with CBC. Paradoxically, in the questionnaire survey there participated only fewer municipalities situated directly at the border than municipalities situated at a further distance with less favourable access to the border with the Czech Republic. Seven frontier municipalities did not participate at all.

\section{Results of questionnaire survey}

The results of questionnaire survey were based on expert evaluation of factors' ranking according to the degree of importance (significance) for cross-border cooperation.

Accessibility of the Nearest Border Cross Point (factor 1, expert score 81 points) was evaluated as the factor with the highest significance and assigned coefficient 5. Next ranking factors: Programme Documents of Municipalities (factor 5 with 78 points, coefficient 4), Partner 
Municipalities (factor 2, 77 points, coefficient 3), Implementation of Projects under the CBC 2004-2006 (factor 4, 76 points, coefficient 2 ) and Experience with the Application for Grants in Programmes CBC 2004-2006 (factor 3, 60 points, coefficient 1).

According to experts, the greatest influence on the intensity of CBC is The Accessibility of the Nearest Border (factor 1). Transport links between municipalities of TSR and CZ provides seven road border crossings. The most significant in terms of the quality of transport infrastructure (road of 1st class) and the availability of municipalities in TSR are the border crossings Drietoma (available from 64 municipalities TSR), Lysá pod Makytou and Horné Srnie (both available from 26 municipalities TSR). Border crossing Moravské Lieskové (available with 21 municipalities TSR) and Vrbovce (8 villages) are located on a second class road. The border crossings Nová Bošáca and Červený Kameň on a 3rd class road have local importance. According to accepted criteria for evaluation, the highest number of 4 points was reached by 33 municipalities, 3 points - 52 villages, 2 points - 48 municipalities, 1 point - 30 municipalities and 4 municipalities - 0 points. The municipalities of the border zone have the shortest distance from the village centre to the state border (Vrbovce $4 \mathrm{~km}$, Lysá pod Makytou $5.5 \mathrm{~km}$, Horné Srnie $6.5 \mathrm{~km}$, et al.) and the city Handlová has the longest distance to the border crossing Drietoma $(92 \mathrm{~km})$. Spatial differentiation of the partial potential of the municipalities in TSR by factor 1 shows that the potential of municipalities for CBC decreases with increasing distance and poorer availability of border points. The highest potential by this factor was reached by villages located next to the state border and in the belt of border municipalities.

According to expert evaluation, the Programme Documents of Municipalities (factor 5) have the second most significant impact on the potential of municipalities for CBC. Only a small number of municipalities have approved development programmes (PESD and other development programmes), which expected potential financing of development plans from CBC programmes. The survey pointed out that 167 municipalities have approved only 87 programming documents and 88 municipalities have not approved any. Mostly they are municipalities with about 2000 inhabitants, situated further from the border with the Czech Republic, with a low budget for further development, preparation and implementation of CBC projects. 73 municipalities has only one programming document and six municipalities have more than 2 documents (Brezolupy, Kostolné, Vad'ovce, Sebedražie, Mestečko and only the city of Handlová has up to 4 programming documents). Spatial differentiation indicates a relatively low correlation between the border position of a settlement and the number of development documents. Municipalities that are located directly in the border belt have usually developed one programme document. On the other hand, Handlová with the highest number of documents (4) belongs to the outlying subregion. It also corresponds to the spatial differentiation of the partial potential of municipalities by factor 5 . Handlová has the highest potential (16 points), followed by Vad'ovce, Kostolné, Sebedražie and Brezolupy (each 8 points).

The third factor was Partner Municipalities, factor 2. Partnership of municipalities is generally very weak. Up to $101(60.4 \%)$ municipalities have no cooperation with municipalities in the Czech Republic. The villages, directly adjacent to the Czech Republic declare at least one partnership. They are the municipalities of all districts in TSR. The category with two partnerships including 5 villages and 4 municipalities (Mníchova Lehota, Horná Súča, Trenčín, Mestečko) report 3 partnerships. Only the village Pruské has five partnerships and 4 municipalities (Prusy, Vel'ké Chlievany, Vad'ovce and Čachtice) report up to 6 partnerships in the Czech Republic. The maximum value of partial potential was reached by the villages Čachtice, Vad'ovce, Prusy and Pruské (each 16 points), they are municipalities quite far from the border. Of the bordering municipalities, Horná Súča and Mestečko have the highest potential according to this criterion (both 9 points). The majority of communities in the border zone achieve low potential in the range of 0 to 3 points.

Another factor according to importance is the Implementation of Projects under the CBC 20042006 (factor 4). In the INTERREG IIIA SK-CZ there have been implemented 17 projects in the position of lead partner in 10 municipalities. A lack of experience caused poor project activity. The most projects were implemented in Myjava (7 projects) and in the border villages (Lysa pod Makytou - 4 projects, 4 municipalities - 2 projects, 3 municipalities - 1 project). The maximum value of the partial potential according to this factor was achieved by the town 
Myjava (12 points), followed by the villages Lysá pod Makytou, Dohňany, Pruské and Brezová pod Bradlom (each 6 points). It is interesting that the district as well as most other towns had very low potential, it means that they had low project activity in $\mathrm{CBC}$ programmes.

The last in degree of importance for the development of CBC is factor 3 - Experience with the Application for Grants in Programmes CBC 2004-2006. In general it can be said that municipalities had relatively poor experience with applications for grants in cross-border cooperation programmes (INTERREG IIIA SK-CZ) in the previous programming period. We can assume that it was affected by poor awareness and shortened programming period 2004-2006. Of the total, only $38(23 \%)$ municipalities submitted at least 1 application for a grant, on the other hand, the town Handlová asked for 10 grants. The highest partial potentials were achieved by Handlová, Myjava, Dohňany, Lednica, Vad'ovce and Mestečko (each 4 points), followed by Čachtice, Drietoma and Uhrovec (each 3 points).

The sum of the partial potentials of municipalities by factors of $F 1$ to $F 5$ is the basis for determining the total potential and final typology of municipalities in TSR, according to potential for CBC. There are municipalities with low (0 to 14 points, 44 municipalities), moderately high (15 to 29 points, 110 municipalities) and high potential (30 or more points, 13 municipalities) (Map 1).

Municipalities in the districts of Trenčín, Myjava, llava and Nové Mesto nad Váhom have the most favourable conditions for CBC (Graph 1). The majority of these municipalities have moderately high to high potential for $\mathrm{CBC}$. On the other hand, in districts of Partizánske, Prievidza and Bánovce nad Bebravou, particularly location and distance from the border negatively affect the potential of municipalities for CBC. In these districts, no municipality has high potential and a small number of settlements reached moderately high potential. In the district Partizánske, all municipalities have a low potential for CBC (Graph 1).

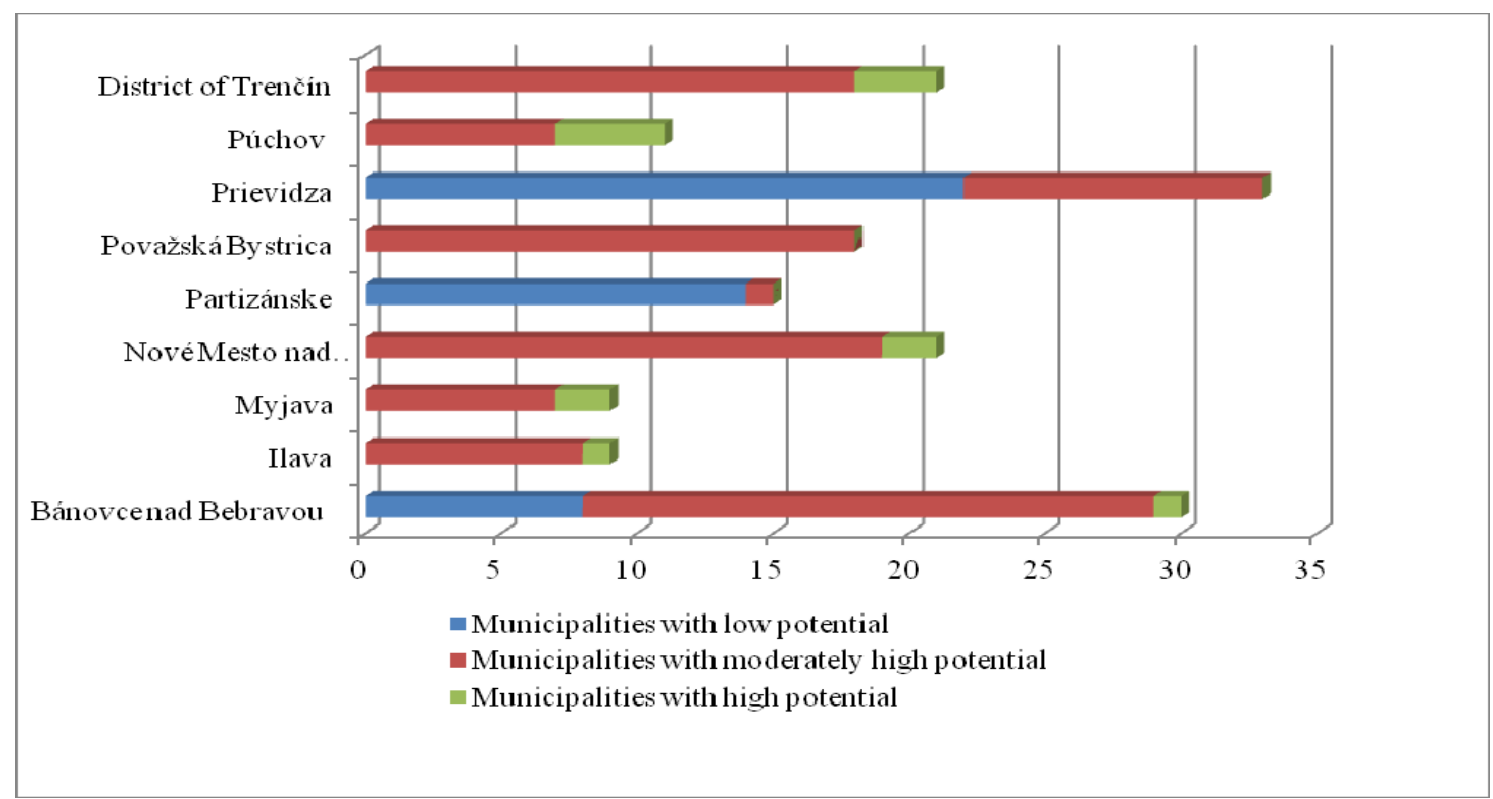

Graph 1. Typology of municipalities of Trenčín self-governing region according to potential for CBC. Source: Questionnaire survey, 09/2011-03/2012.

In TSR there is the largest group of municipalities with moderately high potential. Directly in the border zone the municipalities reach high (Drietoma, Horná Súča, Horné Srnie, Lysá pod Makytou, Dohňany, Zárečie, Mestečko, Myjava) and moderately high (almost all other municipalities, Map 1) potential for CBC.

In the current programming period, the municipalities actively use their potential for $C B C$ and submit projects in the OP CBC SK-CZ 2007-2013. Mainly the municipalities of the border zone and a short distance from the Slovakia-Czech state border and those with experience from the previous programming period are involved in cross-border projects in the position of lead partner. The results of the project activities and use of funds in the OP CBC SK-CZ 2007-2013 
clearly shows that the factor of distance (or proximity to the state border) has become a crucial factor in the active participation of communities in the CBC and cross-border projects. It also shows the spatial differentiation of partner projects (Map 2) and the amount drawn from the budget of the OP CBC SK-CZ 2007-2013 in municipalities of the Slovak-Czech border region (Map 3).

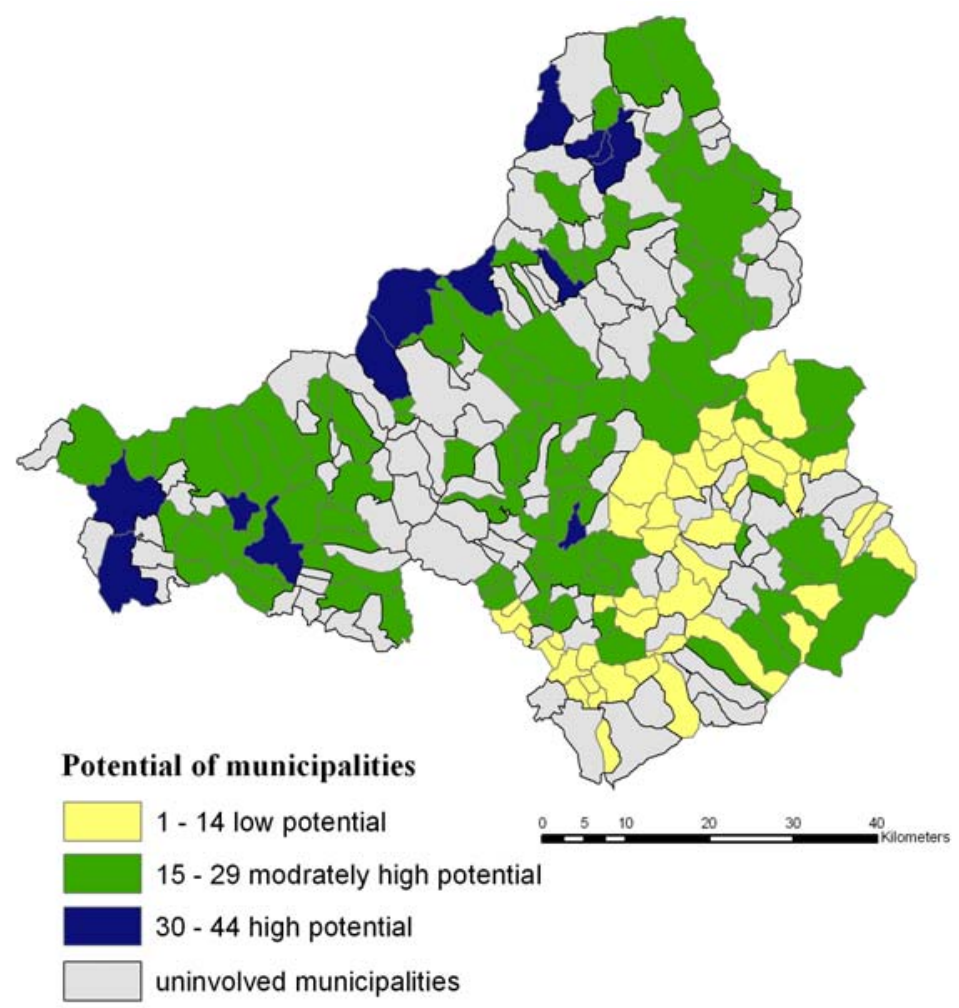

Map 1. Potential of municipalities of Trenčín Self-governing region for CBC. Source: Questionnaire survey, 09/201103/2012.

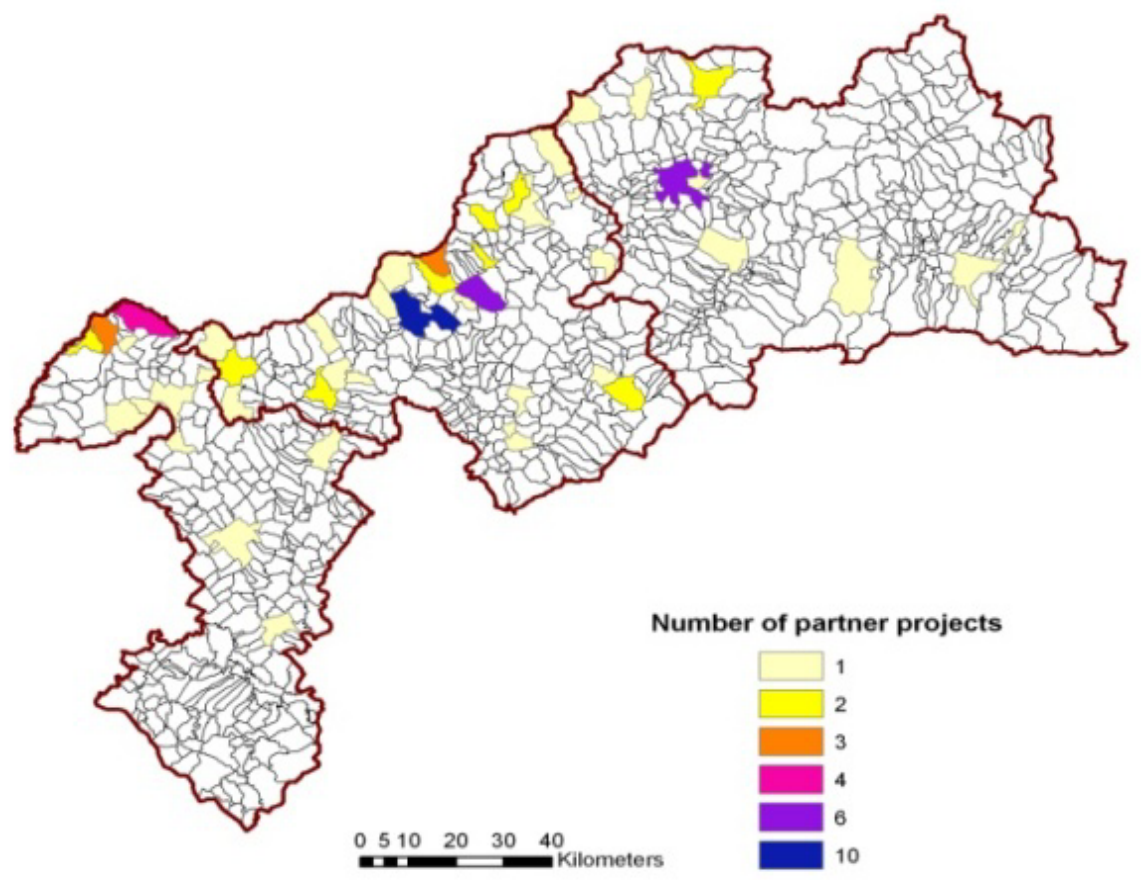

Map 2. Number of partner projects in the Slovak-Czech CB region (31.12.2011).

Source: http://www.monitoringfondov.eu/section.php?cerpanie, [5.10.2012]. 


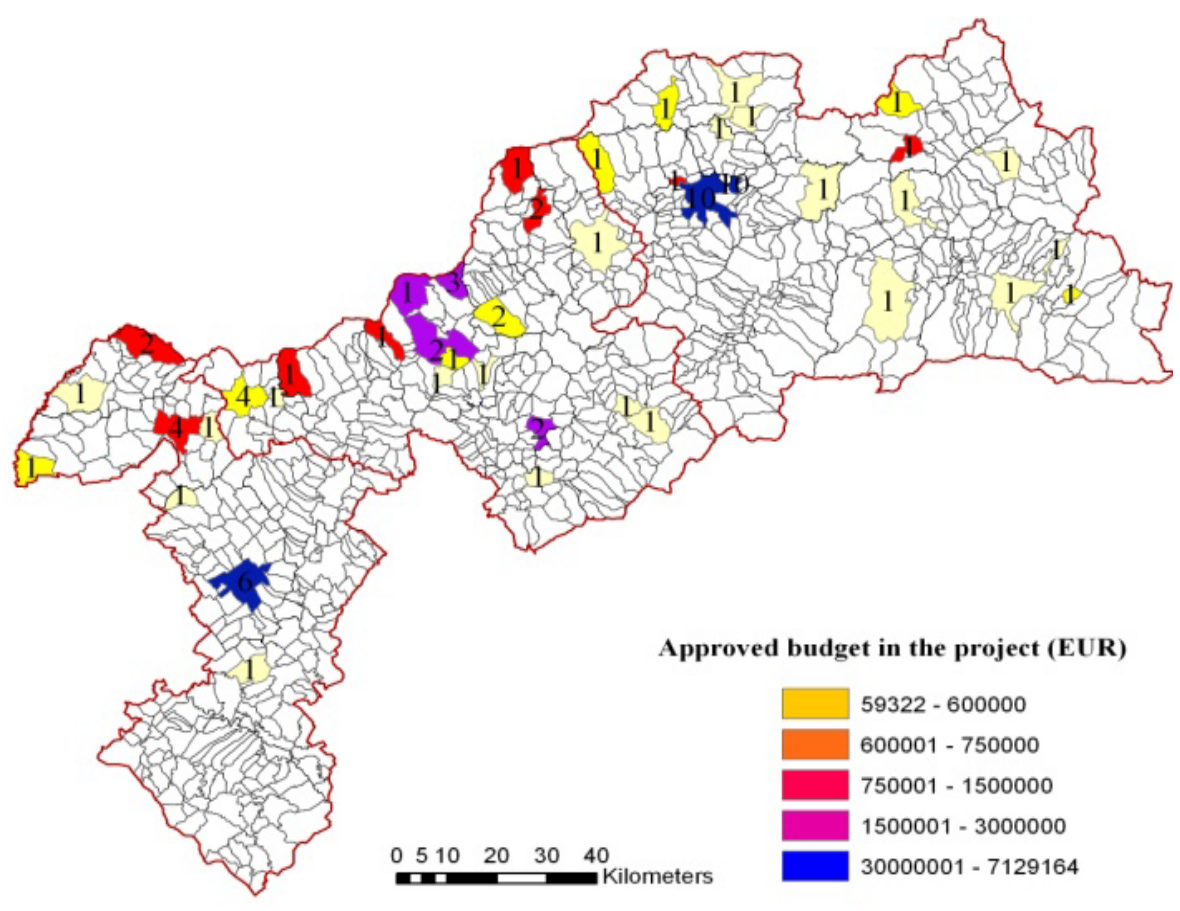

Map 3. Approved budget and number of realized projects in the Slovak-Czech cross-border region (31.12.2011). Source: http://www.monitoringfondov.eu/section.php?cerpanie, [5.10.2012].

\section{Conclusion}

The survey and evaluation of results have contributed to the identification of the main problems of municipalities in TSR for CBC. At the level of local governments of TSR there is only a minimal direct relationship between the intensity of $C B C$ and the distance of municipalities from the border or the number of population. There are also a small number of municipalities with adopted programme documents that declare a solution of development objectives with financial support in the framework of CBC. Municipalities' potential and intensity of CBC only slightly depend on the experience of municipalities with the partnership and $\mathrm{CBC}$ with municipalities in the Czech Republic. The short programming period 2004-2006 also had a negative effect. The activities of local governments in networking and partnerships with municipalities in the Czech Republic were weak, and the majority of municipalities were without a partnership.

According to research the reasons for low intensity of drawing funds on CBC Programme CZSK are:

- Lack of experience with grant applications and project implementation under the CBC programmes,

- Deficit budget for project co-financing,

- Lack of personnel and professional capacity to prepare and implement projects,

- Difficult project administration and implementation,

- A negative influence also has the long duration of partial and final verification of project activities and financial costs. Local governments are getting into financing trouble with the implementation of project activities. It caused a lack of interest of eligible entities to apply for new projects.

The results of the implementation process of the current programming period point out the relatively low financial drawing from OP CBC SK-CZ 2007-2013. On the other hand, the factors of distance and experience significantly affect the project activity of municipalities. 
Municipalities of the Slovakia-Czech border region are more intensely involved in cross-border project activities and use of funds in the OP CBC SK-CZ 2007-2013.

\section{Acknowledgement}

The publishing of the paper is supported by the Visegrad Fund, project Nr. 11220149 "Borders and Borderlands within the Central Europe" and thanks to the financial support of Vega Grant: 1/1143/12: Regions: development, transformation and regional differentiation.

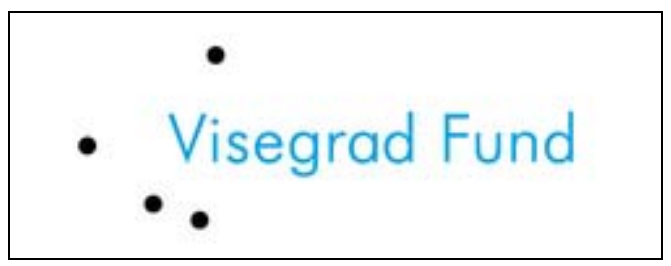

References

[1] Anderson, J., O'Dowd, L., Wilson, T. M. (2003). New Borders for a Changing Europe: Cross-Border Cooperation and Governance. London: Frank Cass.

[2] Dočkal, V. (2005). Přeshraniční spolupráce na východních hranicích České republiky: Růžový obláček a hrana reality. Brno: Masaryk University.

[3] Čerpanie eurofondov. [on line]. Available at:

http://www.monitoringfondov.eu/section.php?cerpanie, [5.10.2012].

[4] Európsky rámcový dohovor o cezhraničnej spolupráci, 1980. Available at: http://webcache.googleusercontent.com/search?q=cache:x2FunkVpOwlJ:www.minv.sk/\%3 Fmedzinarodne-europske-

dokumenty\%26subor\%3D20578+Eur\%C3\%B3psky+r\%C3\%A1 mcov\%C3\%BD+dohovor+o +cezhrani\%C4\%8Dnej+spolupr\%C3\%A1ci,+1980.\&cd=2\&hl=sk\&ct=clnk\&gl=sk, [25.9.2012].

[5] Hermanová, E. (2005). Socioekonomická integrace euroregionů a přihraničních regionů České republiky prostřednictvím společného fondu malých projektů (pp. 7-13). In: Peková, J., Zapletalová, J., eds., Euroregiony, státní správa a samospráva. Ostrava, Ústav geoniky AV ČR.

[6] Falt’an, L'. (2004). Prihraničné regióny a cezhraničná spolupráca. In Falt’an, L'., ed., Regionálny rozvoj Slovenska v európskych integračných kontextoch. Regióny, prihraničné regióny, euroregióny (pp. 8-12). Bratislava: Interlingua.

[7] Halás, M. (2005). Cezhraničné väzby, cezhraničná spolupráca (na príklade slovenskočeského pohraničia s dôrazom na jeho slovenskú čast'). Bratislava: Vydavatel'stvo UK.

[8] Halás, M. (2007). Development of cross-border cooperation and creation of euroregions in the Slovak Republic. Moravian Geographical Reports 15(1), 24-31.

[9] Halás, M., Slavík, V. (2001). Cezhraničná spolupráca a euroregióny v SR (Ciele, realita, perspektívy). Miscellanea geographica 9 (171-180). Plzeň: University of West Bohemia.

[10] Ivaničková, A., Vlčková, V. (2005). Chápanie cezhraničnej spolupráce v navrhovanej regionálnej politike Európske únie v programovom období 2007-2013. Medzinárodné vzt’ahy 3(2), 9-17.

[11] Kadeřábková, J. (2005). Historické aspekty přeshraniční spolupráce v ČR (pp. 25-33). In: Peková, J., Zapletalová, J., eds., Euroregiony, státní správa a samospráva. Ostrava, Ústav geoniky AV ČR. 
[12] Kalužáková, H. (2012). Cross border cooperation Slovakia-Czech republic. Conference proceedings from international scientific internet conference „Young Science 2012“. (p. 3338). Bratislava: School of Economics and Management in Public Administration in Bratislava.

[13] Operačný program cezhraničnej spolupráce Slovenská republika - Česká republika 20072013. [on line]. Available at: http://eurofondy.webnode.sk/slovenska-republika-ceskarepublika/, [20.9.2012].

[14] Rajčáková, E. (2009). Regionálny rozvoj a regionálna politika Európskej únie a Slovenska. Bratislava: Geografika.

[15] Ricq, C. (2006). Handbook of transfortier co-operation. University of Geneva.

[16] Scherer, R., Blatter, J. (1995). Preconditions for successful cross-border cooperation on environmental issues: research results and recom[m]endations for a better practice. Freiburg: EURES, Institute for Regional Studies in Europe.

[17] Trenčiansky samosprávny kraj - schválené projekty. [on line]. Available at: http://www.skcz.eu/sk/uvodna-stranka/programova-dokumentacia/; http://www.tsk.sk/buxus/docs//regional/schvalene_projetky_TSK.pdf, [13.11.2012].

[18] Világy, A., Strážay, T., Benč, V. (2006). Analýza cezhraničnej spolupráce a rozvoja prihraničných regiónov s krajinami $V 4$ a definovanie priorít cezhraničnej spolupráce pre predsedníctvom SR vo V4. Bratislava: Výskumné centrum Slovenskej spoločnosti pre zahraničnú politiku.

[19] Wokoun, R. (2008). Regionální rozvoj: východiska regionálního rozvoje, regionální politika, teorie, strategie a programování. Praha: Linde.

[20] Zoznamy schválených projektov z OP cezhraničnej spolupráce SR-ČR. [on line]. Available at: http://www.sk-cz.eu/sk/uvodna-stranka/zverejnene-zoznamy/, [3.12.2012]. 